\title{
Performing Communicative Language Teaching in Mandarin Mobile Learning
}

\author{
https://doi.org/10.3991/ijim.v15i05.20899 \\ Nurul Ain Chua ${ }^{(\varpi)}$ \\ Universiti Malaysia Terengganu, Terengganu, Malaysia \\ ain. chua@umt.edu.my \\ Goh Ying Soon \\ MARA University of Technology, Terengganu, Malaysia
}

\begin{abstract}
Students should be able to develop their communication abilities instead of just concentrating on translation methods. As a result, Communicative Teaching Language (CLT) had become the most favored approach to achieving the verbal goal as it was known as the most effective strategy to enhance learners' communicative competence. However, it was not a one-size-fits-all approach, and language instructors were advised to integrate educational technology to develop learning for students. Hence, CLT Mandarin mobile learning via personal action research was conducted to determine the extent of the approach on students' oral learning attainment, attitudes, and learners' recommendations during the learning process. The communicative task used in this study was Chatting to Mandarin Native Speakers programme. Pre- and post-oral assessments had been conducted in response to research inquiries. In verifying the reliability and validity of the study, data were triangulated through students' oral assessments, Students' Diaries, Self-Reflective Journals and Focus Group Interviews. The outcomes showed that students enjoyed the activity and improved their confidence and oral competence. Also, they suggested that there should be more language activities. The findings indicated that, when designing CLT technology-integrated projects, an instructor needed to consider students' learning preferences which make the project a success.
\end{abstract}

Keywords - Communicative Tasks; Smartphone Applications; Oral Competency

\section{Introduction}

With the increasing importance of Mandarin, the Malaysian government had called on Malaysian citizens to master a foreign language, including Mandarin through the Government Transformation Programme (KPM, 2013). The difficulty of pronunciation was the most challenging part of learning Mandarin for non-native speakers. Also, a large number of Mandarin teachers still used traditional teaching methods in Malaysia (Ghee, Heng and Shuang, 2012; Teh, Saedah and Wong, 2014), such as the GrammarTranslation Teaching method, which focused on translating texts and teaching grammar 
in Mandarin classrooms. Besides, there was a lack of Mandarin communication between teachers and learners. Furthermore, most students preferred to converse in their mother tongue during their lessons. Thus, what was the purpose of language learning if students were not encouraged to speak the target language during the instruction process? Students should be able to develop their communication competencies instead of just concentrating on translation practices.

As a result, Communicative Language Teaching (CLT) had been identified as an appropriate method to progress students' communicative ability and had been recognized as the most useful language teaching method (Burke 2013; Ellis, 1997; Yu, 2011). CLT improved the linguistic competence of learners through the negotiation of meaning and the targeted use of language. It led to more frequent target languages used during the learning process, and the communicative power of the learners had been valued (Burke, 2012). Furthermore, the CLT approach focused on learning the language as meaning rather than accuracy, which referred to grammar rules and translation (Chacon, 2005).

Besides, Cheng (2015) indicated that learning a new language with a first language helped and reduced students' anxiety. Apart from that, students' proficiency level, personality, and motivation had been identified as factors that affected the achievement of the oral goal. Also, CLT was found not a one-size-fits-all technique. Instead, it interacted with numerous related factors (Bao \& Du, 2015). The researchers suggested that CLT teachers needed to adopt a more sophisticated education technology strategy in their instruction to encourage students to learn. Therefore, this study explored teacher's pedagogical knowledge in the integration of mobile applications in Mandarin learning. The aim was to determine the answers to the following research questions:

1. To what extent are learners' language achievements of CLT mandarin mobile technology?

2. To what extent are learners' reactions performing CLT Mandarin mobile learning tasks?

3. What are the recommendations that learners could make to refine the strategy of CLT Mandarin mobile learning in a classroom learning context?

\section{$2 \quad$ Literature Review}

In recognition of Mandarin's importance to the world, Mandarin became the third language in one of the student aspirations in the Malaysian Education Blueprint (MEB) 2013-2025 (Malaysia Education Blueprint, 2013). Moreover, the National Higher Education Strategic Plan Beyond 2020 (Ministry of Higher Education, 2007) stated that "Third-language proficiency is vital to the development of human capital that drives the k-economy as well as the country towards competitive innovation in the international arena." Hence, Malaysian Higher Institutes had been urged to offer students with learning prospects to be proficient in languages such as Mandarin, Spanish, Tamil, French, or Japanese. Considering this, Malaysia's tertiary education, including the University of Malaysia Terengganu, had begun offering Mandarin language courses to nonnative and international students since 2012. The primary objective of the Mandarin 
curriculum as the third language was for communication purposes (Teh et al., 2014). Students would be able to speak Mandarin at the necessary level of the community after completing their Mandarin courses.

\subsection{Communicative teaching approach}

Communicative Language Teaching (CLT) was a popular education method for the development of learners' communication competence. To certify that the tasks were genuine, the researcher analyzed the tasks based on Nunan's (1989) framework. In the framework, Nunan differentiated between communicative and non-communicative tasks. The learning task should contain six components of goals, input, activities, teacher's role, learner's role, and settings. All the components had specific characteristics. Some of the CLT's typical communicative activities involved role-play, group discussion, and simulation, which emphasized collaboration among peers in real or simulated real-life situations (Ma, 2009).

Through the CLT method, learners used language for communication in addition to mastering the language structure. It focused on the concept of 'communicative competence,' which was the product of educators and linguists (Hedge, 2000; Richards \& Rodgers, 2014). In learning, learners expressed their thoughts and engaged in various forms of communication through the CLT (Widdowson, 1990). Students were encouraged to learn through 'negotiation for meaning.' Therefore, students were expected to interact primarily with each other in the communicative classroom, not with the teacher (Richards \& Rogers, 2014). As a result, students had chances to express their ideas, took risks, and tried to adopt the newly learned language. Furthermore, according to Abbar (2016), CLT focused on authentic learning materials. Authentic materials were referred to as newspapers, signs, magazines, graphic resources, advertisements, graphs, video resources, various audio, and charts.

Undeniably, there had also been some inconsistencies in the CLT. In France, educators were confronted with contextual challenges: cultural conflict, lack of authentic teaching materials, and well-trained teachers (Diallo, 2014). Moreover, in China, Hu (2002) discovered that the most critical potential constraint to produce communicative skills was Chinese culture learning during its early implementation. Besides, there were different philosophical assumptions about teaching and learning. The differences were the views on the responsibilities, valued qualities, and roles of teachers and students, and the learning strategies.

Moreover, Diallo (2014) and Hu (2002), emphasized the role of an instructor in ensuring the effectiveness of CLT. In Denmark, Bao and Du (2015) explored the effects of Task-based language teaching (TBLT), the core of CLT for a beginner learning Chinese as a foreign language. They found that TBLT enhanced participation, enjoyment, created more opportunities for speaking, eased learners' and reduced students' anxiety. However, the problems encountered were the difficulty of balancing learners' different preferences with learning strategies, lack of oral practice, and adequate instructional time support. The researcher suggested that the character of the Chinese language should be considered as important content. In brief, CLT aided students to accomplish a communicative goal, encouraged teachers to use authentic materials intelligently and 
considering other existing factors. Teachers were also suggested to adopt more advanced education technology strategies in the CLT approach to improve students' oral performance effectively.

\subsection{Task-based instruction}

CLT could be performed using a variety of methods, including content-based instruction (CBI) and task-based instruction (TBI). The most widely used process is TBI. The three essential principles of TBI consisted of learner-centered concept, substantive exchange of knowledge concepts and a sequence of steps culminating in the fulfilment of the principle of communicative intent (Ballman, Liskin-Gasparro, \& Mandell, 2001). The TBI aimed to develop learners' communication, linguistic, and interactive skills through a meaningful communication-focused task (Ellis and Shintani, 2014). The TBI guided real-life communication, which accentuated communicative goals and was not limited to grammatical concepts. Students had to know how to explain something and not make statements in a proper grammar structure. These learner-centric activities were designed to allow students to interact with each other to complete a task. This situation was disputed by conventional speaking practices, where the emphasis was on seeking answers through systemic patterns. The principal activities of the TBI were knowledge gaps which provided learners with different but complementary pieces of information that needed to be combined to achieve the action's goal (Ballman et al. 2001). Interaction among students was an essential component of a communicative classroom. Students often contribute to context agreements in which they would request repetition and clarification or use other tools to suggest that understanding was problematic (Lee \& VanPatten, 2003). The TBI enabled learners to develop communication strategies during their language learning process. Effective knowledge sharing was based on the intent of the dialogue, succeeded by a follow-up operation.

As an example of task-based language learning, Gromik (2012) had captured a video by using portable devices. It could contribute to teaching English as a foreign language in Japan by improving the oral trust of the 'learners.' During his research period, all participants had to produce a 30-second video of them speaking English each week. Gromik (2012) realized that "making daily cell phone videos encouraged students to consider the best video production strategies and improved the efficiency of the word output for students." Also, the use of social networks had often been encouraged: Facebook, Twitter, WhatsApp, and others, mainly when it involved people who were more skilled in the target language than learners. For instance, Wong (2013) utilized a personal mobile device to explore how a language learner could develop communication skills by taking pictures and posting them to a wiki. Wong (2013) explored how Singapore learners could contribute to the acquisition of Chinese idioms by using the smartphone to accomplish the mission. Learners took images of their everyday lives by using their smartphones. They applied idioms or conjunctions to make sentences about them and then posted them to a peer review wiki room. The result indicated that such a challenge led to the acquisition of Chinese by Singapore learners by helping them "maximized their learning by leveraging mobile learning opportunities." In Sung 's study (2010), the participants talked extensively about the ventures, while offering a 
few suggestions that would better suit individual learning needs. Researchers had found that education-based projects had been able to develop a communicative language that met students' needs, and it was vital to implement the learning project effectively.

Indeed, when the learning process was meaningful, students were motivated to complete the task and, finally, to achieve a targeted communicative goal. Thus, at the beginning of each lesson, an explanation of learning outcomes, and all activities designed were essential and could assist learners to accomplish oral goals. Knowledge of vocabulary, culture, and grammar had also been taught to complete the communicative intention during the learning events. Essential grammar explanations could help a student to execute a communicative function. Too much grammar information was avoided; however, as it only burdened the student by distracting him or her from the communicative goal (Ballman et al. 2001). Therefore, the learnings of grammar, vocabulary, and culture were not overstressed during the learning process. It was to enable students to communicate with others in a newly learned language. At the same time, their language skills would be developed through communication, which was defined as the expression, interpretation, and negotiation of meaning in each context (Lee \& VanPatten, 2003). In other words, the teachers needed to seek opportunities not only to introduce grammar, vocabulary, and culture into the classroom but also, most notably to attain communication goals through TBI.

In short, most researchers would agree that authentic task-based learning through mobile technology was essential and could bring about innovative changes in teaching and learning. Most teachers had realized that proper guidance was vital and fundamental to the application of technological advancements in education. Thus, teaching techniques had to be flexible and suited students' learning preferences in an authentic environment, considering the various factors related to students' desired communicative learning.

\section{$3 \quad$ Methodology / Materials}

This study was a personal action research study with the teacher-cum-researcher. A total of eleven Mandarin Level 1 students were selected through purposive sampling as research participants. There were three cycles involved in the research process. Smartphone applications used for each of the sequences were subsequently listed. The first cycle smartphone applications were Software Applications (Dictionary-Based) and Web-Based Applications, e.g., Padlet and Oceania. In the second cycle, three other forms were added, including Socialization Applications (WhatsApp), audios, and videos.

Furthermore, in the third cycle, Lingt application was added to use it together with the same applications used in the second cycle. After each reflection, different applications were chosen to address the main issues that emerged in the cycle. The design of communicative tasks was based on Nunan's (1989) framework, as shown in Table 1. 
Table 1. Task Components of Chatting to Native Speakers

\begin{tabular}{l} 
Talking to Mandarin Native Speakers \\
\hline Goals: \\
1. To assess students' prior knowledge. \\
2. To communicate effectively with native speakers. \\
\hline \multicolumn{1}{|c|}{ Input: Prompt questions from Chinese native speakers. } \\
\hline Activities: \\
(1) Understand the prompt questions to communicate effectively with Chinese native speakers. \\
(2) Respond to Chinese native speakers who write comments on their responses. \\
\hline Learner roles: Mandarin learners \\
\hline Teacher roles: Facilitator \\
\hline Setting: Outside the classroom. \\
\hline
\end{tabular}

In this study, one oral assessment was conducted before (OA1) learning activity and another (OA2) after the intervention. This type of evaluation was an easy way to compare the difference between the two test results (Norton, 2009). The researcher used them as repeated measures for the collection of quantitative data. Repeated measures were needed when data were obtained from the same individuals under different conditions (Levin, 1999) and two measurements were required of the same participants (Norton, 2009). In short, this measurement design could provide a convincing argument for the effectiveness of the intervention in practice (Norton, 2009).

The oral assessments focused on students' Spoken Production (simple/advance fullsentence construction). It was to find out students' verbal achievement before and after the CLT mobile instruction. The output of OA1 and OA2 were analyzed based on European Benchmarking Chinese Learning (in Table 2). In the study, students conversed to three Mandarin native speakers in a small group on the topics of Greeting, Personal information, Introduce oneself and Talk to a foreigner, and rubrics of assessments were prepared. The data of the study were triangulated through Self-Reflective Journals, Students' Diaries, Focus Group Interviews, and students' oral assessments. 
Table 2. Can-do Statements (CDS) for Production Spoken (PS)

\begin{tabular}{|c|c|c|c|}
\hline \multirow[t]{2}{*}{ A 1.1} & \multirow{2}{*}{$\begin{array}{l}\text { C-PS1-A1.1-1 } \\
\text { Can produce simple, } \\
\text { mainly isolated phrases } \\
\text { about people and places. }\end{array}$} & A1 & $\begin{array}{l}\text { E-PS1-A1-1 } \\
\text { Can produce simple, mainly isolated phrases about one's own and } \\
\text { others' details (e.g., name, age, gender, birthday, birth/home place, } \\
\text { residence place, nationality, status). }\end{array}$ \\
\hline & & A1 & $\begin{array}{l}\text { E-PS1-A1-2 } \\
\text { Can produce simple, mainly isolated phrases about family members } \\
\text { and appellation. }\end{array}$ \\
\hline A1.2 & $\begin{array}{l}\text { C-PS1-A1.1-1 } \\
\text { Can produce simple, } \\
\text { mainly isolated phrases } \\
\text { about people and places. }\end{array}$ & $\mathrm{A} 1+$ & $\begin{array}{l}1+-1 \\
\text { simple words and phrases to describe people I know. }\end{array}$ \\
\hline A2.1 & $\begin{array}{l}\text { C-PS1-A2.1-1 } \\
\text { Can give a simple de- } \\
\text { scription or presentation } \\
\text { of people, living or work- } \\
\text { ing conditions, daily rou- } \\
\text { tines, likes/dislikes, etc. } \\
\text { as a short series of simple } \\
\text { phrases and sentences } \\
\text { linked into a list. }\end{array}$ & A2 & $\begin{array}{l}\text { E-PS1-A2-1 } \\
\text { Can produce simple, mainly isolated phrases about people and } \\
\text { places close around one's work and life (e.g., colleagues, classmates, } \\
\text { superiors and subordinates, and their corresponding places, compa- } \\
\text { nies, schools). }\end{array}$ \\
\hline
\end{tabular}

\section{$4 \quad$ Results and Findings}

Oral assessments with three Chinese speakers were performed in a group before and after the intervention. The data were used to determine the extent of this approach on students' oral performance based on the EBCL. Based on Mandarin I score, the students who achieved A were grouped as High Achievement Group (HAG). Those who scored A- were grouped as Intermediate Achievement Group (IAG), while those who scored $\mathrm{B}$ and $\mathrm{C}$ were in the Low Achievement Group (LAG). In total, there were six participants in the HAG, two in the IAG, and three in the LAG. The students talked about Greeting, Personal information, Introduce oneself and Talk to a foreigner which were some of the topics of Mandarin Level I. Then, the researcher checked students'sentences production and coded them under the themes of Personal details (A1.1), Introduce Others (A1.1), Family (A1-1) and Character and Physical appearance (A1-2). All sentences produced by the students were grouped under the mentioned themes based on the syllabus of EBCL. The comparison was carried out among the three groups. It was to determine to what extent the achievements of Mandarin students were equivalent to the international standard.

\subsection{Students' oral achievement based on EBCL}

As shown in Table 3, HAG, IAG and LAF students produced language at level A1.1 on the themes of Personal details, Introduce others and My family at OA1. While at $\mathrm{OA} 2$, their performances were shifted from level A1.1 to A2.1(A1+) for the same themes. 
Table 3. Students' Mandarin achievement

\begin{tabular}{|c|c|c|}
\hline \multirow{2}{*}{ Group of students } & \multicolumn{2}{|c|}{ Mandarin achievement } \\
\cline { 2 - 3 } & Oral assessment1(OA1) & Oral assessment2(OA2) \\
\hline HAG & From level A1.1 & From level A1.1 to A2.1(A1+) \\
\hline IAG & From level A1.1 & From level A1.1 to A2.1 (A1+) \\
\hline LAG & From level A1.1 & From level A1.1 to A2.1 (A1+) \\
\hline
\end{tabular}

In summary, the syllabus of the current curriculum was comparable to that of EBCL. It was because most of the students were able to produce the sentences of the Production Spoken (P.S.), as stated in the Can-do Statements (CDS) of EBCL.

\subsection{Students' reactions}

The pieces of evidence extracted from Students' Diaries and students' Focus Group Interview had explained accordingly for each cycle. The results of the first cycle showed that students enjoyed and were motivated by the CLT Mandarin Mobile Learning. The results of the second cycle indicated that the confidence levels of Mandarinspeaking students had increased as they tried hard to understand and respond to prompt questions from native speakers. Data from the third cycle implied that the students loved, enjoyed, and worked hard to learn Mandarin. In summary, most of the students perceived that their oral skills had improved and were eager to learn Mandarin II. Other evidence was from Teacher Self-Reflective Journals. The students displayed their achievements which were stated as follows. '... they were able to converse with a simple sentence, create and share flashcards, prepare to develop and learn through flashcards; independent learning and students can use the application quickly, they had been able to understand YouTube, answer given questions, and create dialogues'

\subsection{Students' recommendations}

All students loved CLT, Mandarin mobile learning activities, and wanted this way of learning to continue in the future. They suggested that there should be more language practices and language activities. However, students' abilities to converse with native speakers and their pinyin pronunciation still needed to be improved and well-guided. The finding revealed that the students' learning styles had been a crucial factor in ensuring the success of this approach. Thus, the teacher needed to gauge students' learning style before starting the lesson in future lessons. It was intended to ensure that CLT Mandarin mobile learning could cater to the different learning needs of students. For instance, using slide show/PowerPoint, pictures, or videos to suit the preferences of visual learning students, they had to be fitted to learning purposes. Next, the teacher should plan more oral activities inside or outside the classroom via mobile applications, and the teacher had to pay more attention to oral practice as well as to provide ample of oral opportunities to students. 


\section{Conclusion}

This finding was related to the theory of socio-cultural and connectionism. In sociocultural theory, learning happened through meaningful interactions among communication partners, which was reflected in the CLT approach and the TBL in Second Language Acquisition. Students learned Mandarin not so much about forms, words, and sentence structures, but rather about concepts or notions for the communicative aims. In this digital era, learning Mandarin via the smartphone application supported the theory of connectionism; learning happened when students were connected to all the related sets of information with the students' current knowledge from different databases. CLT Mandarin mobile learning had made it possible for foreign language teachers to meet the needs of new millennium learners. The 'digital natives' and 'net generation' were quickly attracted to and engaged in a kind of lesson. These new technologies had given teachers with a wealth of innovative opportunities that provided the students with choices to create tasks, to use games, to interact with others, to explore media, and to engage students in language and culture simulations (Scarino and Liddicoat, 2009).

The finding suggested that students were self-regulated learners. They had learned through the connection of information from different databases within their networks; this was what made learning happened. This finding was parallel to the literature that discovered iPad usage had improved the quality and quantity of students' oral performance (Lys, 2013). The mobile device of iPad had enabled learners to access resources and learned at their own pace, place, and time. It was the same thing as the findings of this current study. Students used smartphones to accomplish all the communicative tasks during the instruction.

Moreover, the capabilities of the smartphone had allowed the use of precious learning materials in multimodal ways (Jarvis, 2013). Wang and Smith's study (2013) revealed that learning via mobile devices had led to a positive learning attitude and that students considered it as an effective way to improve their reading and grammar skills. This self-regulated learning was agreeable with the Vygotsky's intra-psychological learning, and when dealing with others, it suited to inter-psychological knowledge. Students constructed new experiences when chatting with Chinese native speakers that had enhanced their vocal performance during the learning process. Besides, students gained new skills through group discussion activities, language games, oral presentations, tutorials, questioning and answering sessions. Hence, this current study was in parallel with the view of constructivists. The theory of the use of socio-cultural and technological tools promoted active learning to achieve real-life communicative goals. Also, this study adopted the ecological constructivism of the aspects of Vygotsky's (1978) notions of Zone of Proximal Development, as well as the modelling and scaffolding of situated cognition and collaborative learning, in which learning with native learning was highly beneficial.

In this study, students were active, autonomous, and collaborative in the same way that Hoven and Palalas (2011) mentioned; students co-constructed meaning for themselves and others. Technology-enhanced instruction fostered a high degree of learning control by the learner and improved communicative competences in an autonomous way as proposed by Seiz-Ortiz and Romero-Forteza (2013). In other words, the learning 
responsibility had been transferred to the learners. Furthermore, such awareness helped learners to embrace self-learning. Results were in line with Swain's (1995) hypothesis that, by noticing the functions of output, learners were assisted to see gaps in their interlanguage. For example, synthetic processing occurred when the second language sentences were pronounced, rather than attending the production. Therefore, extensive opportunities for output production could result in the noticing of specific structures by the learners.

Concerning fluency and accuracy, students were able to produce more sentences during their oral performances. Students enjoyed chatting with native speakers and learning using smartphone applications. They had acquired a lot of new Mandarin words via mobile applications. It was known that vocabulary or lexicon was often considered to be the basis of all languages. Wilkins (1972) had ever stated that when a language learner did not have enough grammar, only a little message could be conveyed. However, if the learner did not have enough the vocabulary, nothing could be expressed. The crucial of vocabulary had been stressed by Hatch (1983). The lexicon was crucial to make the necessary communication possible to achieve the communication goal. Vocabulary acquisition could serve as an indicator of their proficiency level in the target language. According to recent research, students' quotations/results of the oral assessment indicated that students gained many new vocabularies. From the analysis, the codes of full sentences under the theme of comprehensibility were increased in OA2 compared to OA1. It had shown that the ability and smoothness (fluency) in producing complete Mandarin sentences had been enhanced. Students could respond spontaneously while talking to native speakers. Moreover, students perceived that they were more confident in speaking Mandarin with native speakers in the second conversation than they were able to Chinese tones better than in the first conversation. Lin, Kao, and Lan (2016) pointed out that perhaps the advancement of mobile technologies could offer timely help when they encountered any problems while communicating with others in the target language.

In this study, students inclined to make mistakes in pinyin; however, in CLT, students learned better and were able to produce more sentences without too much stress on pinyin pronunciation. The improvement allied with the finding by Chao (1998) and Krashen (1982) that the more teachers stressed their accuracy, the more anxious students would be, and this would discourage them from communicating in the target language.

In conclusion, this study showed that the researcher was able to motivate and encourage students to enhance their Mandarin learning, particularly in the oral aspect. However, the teacher needed to tailor her pedagogy skill to suit the diversity of the students, technology, and content; to produce a satisfactory result. The teacher-cumresearcher had committed to implementing all the recommendations made by the learners during the cycles. Research and self-regulated would be an ongoing process, and the teacher's 'tailoring skill' needed to be enhanced to suit the diversity of students. Although the researcher had made progress in integrating smartphone applications into CLT Mandarin education, this remained a challenge. Expanded use of all advanced technology tools and social media were areas that the researcher planned to explore with her students in the future semesters. The researcher hoped that this study on the 
efforts to integrate smartphone applications into CLT would encourage other educators to consider the possibilities and the promises. The sharing of experience in this study enriched the teaching of Chinese as a foreign language and was transferable to the teaching of all foreign languages in general.

\section{$6 \quad$ References}

[1] Abbar, M. E. (2016). A Lesson Study of Internet Usage to Enhance the Development of English Language Teaching in a Libyan University. A thesis in teaching English. Ph.D. thesis, University of East Anglia, Libyan.

[2] Ballman, L. T., Liskin-Gasparro, E. J., \& Mandell, B. P. (2001). The communicative classroom (Vol. III). Boston: Heinle \& Heinle.

[3] Bao, R., \& Du, X. (2015). Implementation of task-based language teaching in Chinese as a foreign language: benefits and challenges. Language, Culture and Curriculum, 28 (3), 291310. https://doi.org/10.1080/07908318.2015.1058392

[4] Burke, B. M. (2011). Rituals and beliefs ingrained in world language pedagogy: Defining deep structure and conventional wisdom. Journal of Language Teaching and Research, 2(1), 1-12. https://doi.org/10.4304/jltr.2.1.1-12

[5] Burke, B. M. (2013). Experiential professional development: A model for meaningful and long- lasting change in classrooms. Journal of Experiential Education, 36(3), 247-263. https://doi.org/10.1177/1053825913489103

[6] Chacón, C. T. (2005). Teachers' perceived efficacy among English as a foreign language teacher in middle schools in Venezuela. Teaching and Teacher Education, 21, 257-272. https://doi.org/10.1016/j.tate.2005.01.001

[7] Chao, D. (1998). Attitudes toward speaking Chinese in an immersion program: The effects on language learning. Journal of the Chinese Language Teachers Association, 33, 1-16.

[8] Diallo, I. (2014) English in education policy shift in Senegal: From traditional pedagogies to communicative language teaching, International Journal of Pedagogies and Learning, 9: 2, 142-151. https://doi.org/10.1080/18334105.2014.11082027

[9] Ellis, R. (1997). SLA Research and Language Teaching. Oxford: Oxford University Press.

[10] Ellis, R. and Shintani, N. (2014). Exploring language pedagogy through second language acquisition research. London and New York: Routledge. https://doi.org/10.4324/ 9780203796580

[11] European Benchmarking Chinese Language (EBCL) (2012). Retrieved October 10, 2017, Retrieved from http://ebcl.eu.com/Ghee, T. T., Heng, L. T., \& Shuang, G. C. (2012, July). Students' perception on using podcast in learning Mandarin. In International Conference on Education and e-Learning Innovations (pp. 1-6). IEEE. https://doi.org/10.1109/ iceeli.2012.6360574

[12] Gromik, N. A. (2012). Cell phone video recording feature as a language learning tool: A case study. Computers \& Education, 58, 223-230. https://doi.org/10.1016/j. compedu.2011.06.013

[13] Hatch, E. (1983). Simplified input and second language acquisition. In R. W. Andersen (Ed.), Pidginization and Creolizaton as language acquisition. City, MA: Newbury House. https://doi.org/10.1017/s0272263100006100 
[14] Hedge, T. (2000). Teaching and Learning in the Language in Language Classroom. Oxford: Oxford University Press.

[15] Hoven, D., \& Palalas, A. (2011). Reconceptualising design approaches for mobile learning language. CALICO Journal, 28(3), 699-720. https://doi.org/10.11139/cj.28.3.699-720

[16] Hu, G. (2002). Recent important developments in secondary English-language teaching in the People's Republic of China. Language, Culture, and Curriculum 15, 30-49. https://doi.org/10.1080/07908310208666631

[17] Kementerian Pendidikan Malaysia/KPM (2013). Pelan Pembangunan Pendidikan Malaysia 2013-2025. Retrieved October 1, 2016, from https://www.moe.gov.my/index.php/dasarmenu/pelan-pembangunan-pendidikan-2013-2025 https://doi.org/10.2139/ssrn.2302609

[18] Krashen, S. D. (1982). Principles and Practice in Second Language Acquisition (First; S. Krashen, ed.). California: Pergamon Press Inc.

[19] Lee, J. F., \& VanPatten, B. (2003). Making communicative language teaching happen (2nded.). Boston: McGraw-Hill.

[20] Levin, I. P. (1999). Relating Statistics and Experimental Design. London and Thousand Oaks: SAGE Publications, Inc.

[21] Lin, Y-T., Kao, C-L. and Lan, Y-J. (2016) 'The effects of mobile learning on students' oral performance in Mandarin Chinese and their attitudes', Int. J. Mobile Learning and Organisation, Vol. 10, Nos. 1/2, pp.78-101. https://doi.org/10.1504/ijmlo.2016.076191

[22] Lys, F. (2013) 'The development of advanced learner oral proficiency using iPads'. Language Learning \& Technology, Vol. 17, No. 3, pp.94-116.

[23] Malaysia Education Blueprint (2013). Malaysia Education Blueprint 2013 - 2025. Education, 27(1), 1-268.

[24] Ministry of Higher Education. (2007). The National Higher Education Strategic Plan beyond 2020. Retrieved December 18, 2016, from www.moe.gov.my

[25] Norton, L. S. (2009). Action Research in Teaching and Learning (A Practical Guide to Conducting Pedagogical Research in Universities). London and New York: Routledge. https://doi.org/10.4324/9780203870433

[26] Nunan, D. (1989). Designing Tasks for the Communicative Classroom. New York: Cambridge University Press.

[27] Richards, J. C. and Rodgers, T. S. (2014) Approaches and Methods in Language Teaching. 3rd edn. Cambridge: Cambridge University Press.

[28] Scarino, A., \& Liddicoat, A. (2009). Teaching and learning languages: A guide. Melbourne: Curriculum Corporation.

[29] Seiz-Ortiz, R., \& Romero-Forteza, F. (2013). Pedagogical evaluation of web-based autonomous language learning. Glasgow, 10-13 July 2013 Papers, 302.

[30] Sung, K.-Y. (2010). Promoting Communicative Language Learning through Communicative Tasks. Journal of Language Teaching and Research, 1(5), 704-713. https://doi.org/10.4304/jltr.1.5.704-713

[31] Swain, M. (1995). Three functions of output in second language learning. Principles and Practice in Applied Linguistics: Studies in Honor of HG Widdowson, 125-144.

[32] Teh, H.S, Saedah, S., \& Wong, S.L. (2014). Penilaian kurikulum pengajaran bahasa mandarin komunikatif: satu kajian pendekatan iluminatif. Jurnal Kurikulum \& Pengajaran Asia Pasifik, Bil 1(2), 20-31. https://doi.org/10.24042/albayan.v8i2.360 
[33] Vygotsky, L.S. (1978). Mind in Society: The Development of Higher Psychological Processes, Harvard University Press, Cambridge, MA.

[34] Wen-Wen Cheng (2015) A case study of action research on communicative language teaching, Journal of Interdisciplinary Mathematics, 18:6, 705-717, https://doi.org/10.1080/ $\underline{09720502.2015 .1108075}$

[35] Widdowson, H. G. (1990). Aspects of language teaching. Oxford: Oxford University Press.

[36] Wilkins, D. (1972). Linguistics in language teaching. London: Edward Arnold.

[37] Wong, L-H. (2013) 'Analysis of students' after-school mobile-assisted artefact creation processes in a seamless language learning environment'. Educational Technology \& Society, Vol. 16, No. 2, pp.198-211.

[38] Yu, L. (2011). Communicative language teaching in China. 空中英语教室 (社会科学版), 194-198. https://doi.org/10.2307/3587868

\section{$7 \quad$ Authors}

Nurul Ain Chua, currently works as a lecturer at Department of Language and communication, Universiti Malaysia Terengganu, 21030 Kuala Nerus, Terengganu, Malaysia Email: ain.chua@umt.edu.my

Goh Ying Soon, currently works as a Senior Lecturer at Academy of Language Studies, MARA University of Technology, Terengganu, Malaysia.

Article submitted 2021-01-03. Resubmitted 2021-02-13. Final acceptance 2021-02-14. Final version published as submitted by the authors. 